\title{
A gene with homology to the myc similarity region of MyoD1 is expressed during myogenesis and is sufficient to activate the muscle differentiation program
}

\author{
Diane G. Edmondson and Eric N. Olson \\ Department of Biochemistry and Molecular Biology, The University of Texas M.D. Anderson Cancer Center, Houston, Texas \\ 77030 USA
}

MyoD1 is a nuclear phosphoprotein that is expressed in skeletal muscle in vivo and in certain muscle cell lines in vitro; it has been shown to convert fibroblasts to myoblasts through a mechanism requiring a domain with homology to the myc family of proteins. The $\mathrm{BC}_{3} \mathrm{H1}$ muscle cell line expresses skeletal muscle-specific genes upon exposure to mitogen-deficient medium, but does not express MyoD1 at detectable levels. To determine whether $\mathrm{BC}_{3} \mathrm{H1}$ cells may express regulatory genes functionally related to MyoD1, a cDNA library prepared from differentiated $\mathrm{BC}_{3} \mathrm{H1}$ myocytes, was screened at reduced stringency with the region of the MyoD1 cDNA that shares homology with c-myc. From this screen, a cDNA was identified that encodes a major open reading frame with $72 \%$ homology to the myc domain and basic region of MyoD1. The mRNA encoded by this MyoD1-related gene is expressed in skeletal muscle in vivo and in differentiated skeletal myocytes in vitro and is undetectable in cardiac or smooth muscle, nonmuscle tissues, or nonmyogenic cell types. During myogenesis, the MyoD1-related mRNA accumulates several hours prior to other muscle-specific mRNAs and therefore represents an early molecular marker for entry of myoblasts into the differentiation pathway. Transient transfection of $10 \mathrm{~T}^{1} / 2$ or $3 \mathrm{~T}^{3}$ cells with the MyoD1-related cDNA is sufficient to induce myosin heavy-chain expression and to activate a reporter gene under transcriptional control of the muscle creatine kinase 5' enhancer, which functions only in differentiated myocytes. Expression of this cDNA in stably transfected $10 \mathrm{~T}^{1 / 2}$ cells also leads to fusion and muscle-specific gene expression upon exposure to mitogendeficient medium. Thus, the product of this MyoD1-related gene is sufficient to activate the muscle differentiation program and may substitute for MyoD1 in certain developmental situations. Together, these results suggest the existence of a family of myogenic regulatory genes that share a conserved motif with c-myc.

[Key Words: MyoD1; myc similarity region; myogenesis; muscle differentiation]

Received February 21, 1989; revised version accepted March 27, 1989.

Expression of a differentiated muscle phenotype involves determination of pluripotent stem cells to the myogenic lineage and subsequent differentiation to form terminally differentiated myotubes that express an array of muscle-specific genes. Conversion of stem cells to the myogenic lineage appears to be directed by a hierarchy of regulatory genes. Initial evidence for such regulatory genes was obtained by Jones and co-workers, who showed that brief exposure of the embryonic mouse fibroblast line $\mathrm{C} 3 \mathrm{H} 10 \mathrm{~T}^{1 / 2}$ to 5 -azacytidine was sufficient to generate stable cell lineages that differentiated into myocytes, adipocytes, and chondrocytes (Constantinides et al. 1977, 1978; Taylor and Jones 1979, 1982). Conversion of $10 \mathrm{~T}^{1} \mathrm{1} / 2$ cells into determined cell lineages is presumed to be due to incorporation of 5-azacytidine into DNA, resulting in hypomethylation and subsequent activation of specific regulatory loci (Jones and Taylor 1980). The high frequency of conversion to myo- blasts (up to $50 \%$ ) led Konieczny and Emerson (1984) to propose that one locus, or a few closely linked loci, was responsible for establishment of the myogenic lineage. This hypothesis was supported by transfection studies in which genomic DNA from 5-azacytidine-derived myoblasts, mouse $\mathrm{C} 2 \mathrm{C} 12$ myoblasts, and quail embryonic myoblasts was shown to generate myogenic clones from $10 \mathrm{~T}^{1} / 2$ cells with frequencies consistent with a single myogenic regulatory locus (Konieczny et al. 1986; Lassar et al. 1986). The existence of a myogenic regulatory gene was demonstrated directly by Davis et al. (1987), who identified a cDNA, referred to as MyoD1, that converts fibroblasts to myoblasts when placed under transcriptional control of a strong viral long terminal repeat (LTR). Emerson and co-workers also obtained evidence for a myogenic regulatory gene, referred to as myd, which directs myogenic conversion when transfected into $10 \mathrm{~T}^{1} / 2$ cells as cloned unmethylated genomic DNA 
(Pinney et al. 1988). MyoD1 expression is activated in myd transfectants, which led to the proposal that these genes may function sequentially in a dependent myogenic regulatory pathway.

While MyoD1 and myd clearly play important roles in establishing the myogenic lineage, there is considerable evidence for the involvement of additional regulatory genes in myogenic determination and differentiation. Exposure of $10 \mathrm{~T}^{1 / 2}$ cells to 5-azacytidine, for example, gives rise to myoblasts at high frequency, whereas other fibroblast lines are converted at low frequency, suggesting that $10 \mathrm{~T}^{1} / 2$ cells may already express one or more genes that are involved in conversion to the myogenic lineage (Taylor and Jones 1979). Similarly, cells of mesodermal origin are more efficiently converted to myoblasts by MyoD1 than are nonmesodermally derived cells (Davis et al. 1987). These observations suggest that MyoD1 may normally cooperate with additional genes to confer the myogenic phenotype. Additional evidence for positive and negative myogenic regulatory factors has been provided by heterokaryon experiments (Blau et al. 1983, 1985; Wright and Aronoff 1983; Wright 1984). Finally, the mouse muscle cell line $\mathrm{BC}_{3} \mathrm{Hl}$ does not express MyoD1 at detectable levels (Davis et al. 1987), yet these cells express skeletal muscle-specific gene products upon exposure to mitogen-deficient medium (Munson et al. 1982; Olson et al. 1983, 1984, 1986; Caffrey et al. 1987; Hu and Olson 1988; Kelvin et al. 1989). Thus, it is reasonable to predict that expression of a differentiated muscle phenotype may involve interactions between multiple regulatory genes.

Following conversion of stem cells to the myogenic lineage, the muscle differentiation program becomes subject to negative control by serum mitogens and certain nonmitogenic peptide growth factors (Konigsberg 1971; Linkhart et al. 1981; Konieczny and Emerson 1985; Lathrop et al. 1985; Florini et al. 1986; Olson et al. 1986; Spizz et al. 1986; Clegg et al. 1987). Recent studies have implicated various oncogene products in the intracellular pathway whereby growth factors suppress myogenesis. In particular, c-myc, a putative intranuclear mediator of growth factor signals (Kelly et al. 1983; Armelin et al. 1984), has been shown to be downregulated prior to the onset of differentiation, and deregulated c-myc or v-myc alleles have been shown to delay or to prevent the induction of muscle-specific genes (Falcone et al. 1985; Denis et al. 1987; Endo and Nadal-Ginard 1987; Schneider et al. 1987; Spizz et al. 1987). Oncogenic ras proteins, which are thought to activate specific intracellular growth factor cascades (Barbacid 1987), have also been shown to prevent the normal decline of c-myc and to block the morphological and molecular events associated with myogenesis (Caffrey et al. 1987; Olson et al. 1987; Payne et al. 1987; Gossett et al. 1988; Kelvin et al. 1989).

The potential involvement of $\mathrm{c}-\mathrm{myc}$ in suppression of myogenesis is intriguing, considering that MyoDl converts fibroblasts to myoblasts through a mechanism requiring a segment similar to a conserved region of the myc family of proteins (Tapscott et al. 1988). In light of the importance of the myc homology of MyoD1 for myogenic conversion and the antagonistic roles of c-myc and MyoD1 in the control of myogenesis, we explored the possibility that $\mathrm{BC}_{3} \mathrm{H} 1$ cells, which appear to be MyoD1-independent, might express MyoD1-related genes sharing the myc homology. Here, we describe a MyoD1-related cDNA that was identified by screening cDNA libraries from $\mathrm{BC}_{3} \mathrm{H} 1$ myocytes, as well as $\mathrm{C} 2$ myotubes, at reduced stringency with a segment of the MyoDl cDNA corresponding to the myc-like domain. The mRNA encoded by this MyoDl-related gene is expressed in differentiated myocytes in vitro and in skeletal muscle in vivo, with no detectable expression in cardiac or smooth muscle, nonmuscle tissues, or nonmyogenic cell types. During myogenesis, this mRNA accumulates several hours prior to other muscle-specific mRNAs and thus represents an early marker for entry of myoblasts into the differentiation pathway. Sequence analysis of the MyoD1-related cDNA reveales $72 \%$ homology at the amino acid level to a region encompassing the basic and myc-similarity regions of MyoD1. Expression of the MyoD1-related cDNA in stably or transiently transfected $10 \mathrm{~T}^{1} / 2$ cells is sufficient to establish a regulatory program that leads to expression of muscle-specific genes upon exposure to mitogen-deficient medium. Together, these results provide evidence for a family of myogenic regulatory factors that share a conserved motif with c-myc and suggest that the product of this MyoD1related gene functions, either directly or indirectly, as a transcriptional activator of multiple muscle-specific genes.

\section{Results}

Screening of myocyte cDNA libraries with MyoD1 at low stringency and identification of a MyoD1related $c D N A$

Our initial interest was to investigate whether the $\mathrm{BC}_{3} \mathrm{H} 1$ muscle cell line, which does not express MyoD1 at detectable levels (Davis et al. 1987), might express a functionally related gene product. $\mathrm{BC}_{3} \mathrm{H} 1$ cells exhibit a fibroblast-like morphology when maintained at low density in mitogen-rich medium (Schubert et al. 1974). Upon exposure to mitogen-deficient medium, these cells cease dividing and express an array of muscle-specific genes. However, unlike other skeletal myoblasts, $\mathrm{BC}_{3} \mathrm{H} 1$ cells withdraw reversibly from the cell cycle and do not fuse or become committed to terminal differentiation (Munson et al. 1982; Olson et al. 1983, 1984, 1986; Strauch and Rubinstein 1984; Lathrop et al. 1985; Spizz et al. 1986; Strauch et al. 1986; Hu and Olson 1988).

To investigate whether $\mathrm{BC}_{3} \mathrm{Hl}$ cells might express a myogenic regulatory gene related to $\mathrm{MyoD} 1$, a cDNA library prepared from the poly $(A)^{+}$mRNA of differentiated $\mathrm{BC}_{3} \mathrm{Hl}$ myocytes was screened at low stringency with a 221-bp fragment of the MyoD1 cDNA. The DNA fragment used for the screen encompassed the region of MyoD1 that shows similarity to a conserved sequence within chicken $c-m y c$ and $v-m y c$, human and mouse c-myc, mouse L-myc and $\mathrm{N}-m y c$, and the predicted 
$\mathbf{A}$

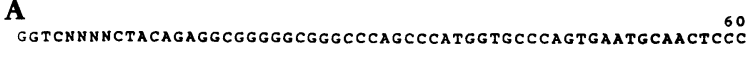
AGGGGCCCTCNNCTGCGGGACGTTGGGGGCCAGTGGCAGGAaCAaGCCTTTTGCGACCTG AtgGagctgtatgagacatccccctattTctaccagGagccccactrctatgatgGgGo 180

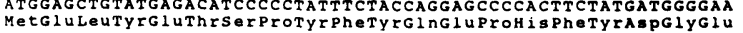

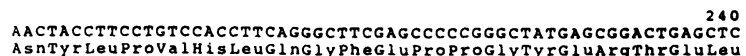
AGCTTAAGCCCGGAAGCCCGAGGGCCCCTGGAAGAAAAGGGACTGGGGACCCCTGAGCAT

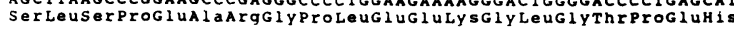

TGTCCAGGCCAGTGCCTGCCGTGGGCATGTAAGGTGTGTAAGAGGAaGTCTGTGTCGGTG

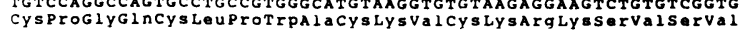

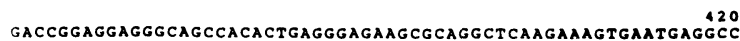

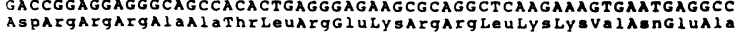

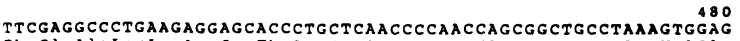

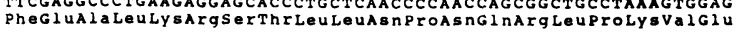

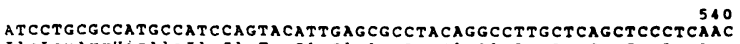

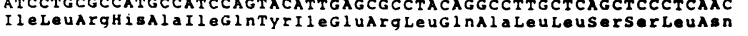
CAGGAGGAGCGCGATCTCCGCTACAGAGGCGGGGGCGGGCCAGCCCATGGTGCCCAGTG

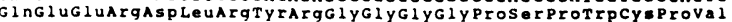

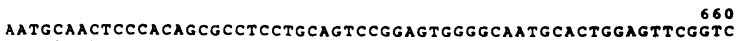

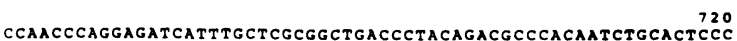

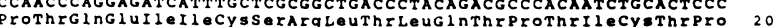

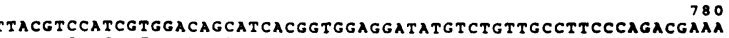

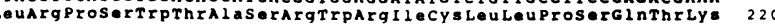

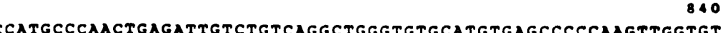

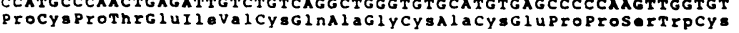

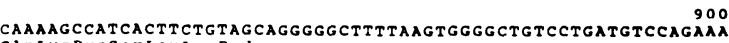
GInLysproserbeuleuEnd

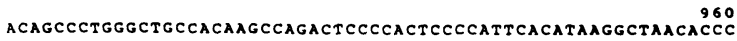

B

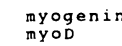

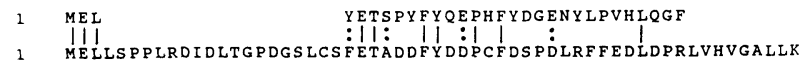

31 EPPGYERTELSLSPEARGPLEEKGLGTPEHCPGQCLPWACKVCKRKSVSVDRRRAAT

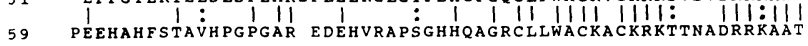

88 LREKRRLKKVNEAFEALKRSTLLNPNQRLPKVEILRHAIQYIERLQALLSSLNQEERD

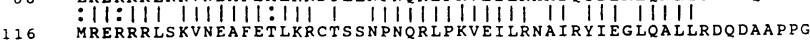

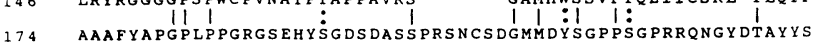

96 TICTPLRPSWTASRWRICLLPSQTKPCPTEIVCQAGCACEPPSWCQKPSLL

232 EAVRESRPGSAAVSLDCLSSIVERISTDS 11

277 SPPGPPEGASLSDTEQGTQTPSPDAAPQCPAGSNPNAIYQVL

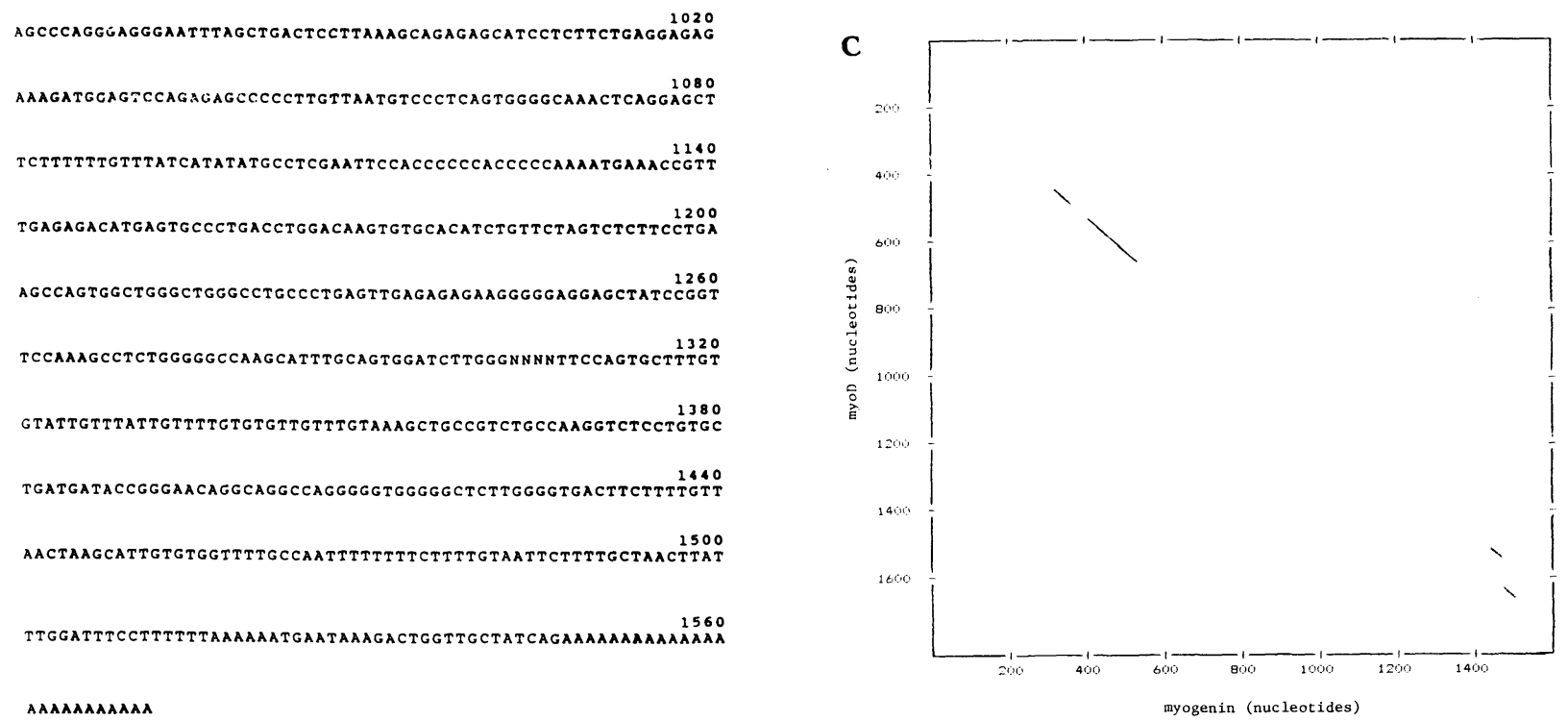

Figure 1. Nucleotide and predicted amino acid sequence of the MyoD1-related cDNA and homology to MyoD1. (A) The nucleotide sequence of the MyoD1-related cDNA is shown with the longest uninterrupted ORF. The cDNA shown was isolated from a C2 cDNA library. Sequence comparison with a rat cDNA clone for myogenin isolated by Woody Wright and co-workers (Wright et al. 1989) revealed $92 \%$ homology between the two sequences. $(B)$ Homology between the predicted amino acid sequences of the MyoD1-related cDNA and MyoDl are indicated. Bars indicate identity and dots indicate conservative amino acid substitutions. $(C)$ Dot matrix analysis of MyoDl and the MyoDl-related cDNA (myogenin). Diagonal lines indicate homology between the two cDNAs.

products of the Drosophila achaete-scute locus, which is involved in neurogenic determination. We selected this region from MyoDl as a probe because of the demonstrated importance of the myc homology for myogenic conversion and because of the ability of $c-m y c$ to antagonize myogenesis. A cDNA library from C2 myotubes, which express MyoD1, was screened in parallel with the same probe.

Several putative MyoD1-related cDNA clones were identified within the $\mathrm{BC}_{3} \mathrm{H} 1$ and $\mathrm{C} 2$ cDNA libraries from the low-stringency screens. The majority of positive clones from the C2 library encoded MyoD1; how- 
ever, one of these positive clones was found to hybridize to the labeled probe at low stringency, but only weakly under high-stringency conditions. Sequence analysis of this clone and two clones from the $\mathrm{BC}_{3} \mathrm{Hl}$ library showed that they corresponded to the same gene product. The largest of the cDNAs was obtained from the C2 library and was $1571 \mathrm{bp}$ in length. Within this cDNA was a single major uninterrupted open reading frame (ORF) preceded by a sequence (ACCTGATGG) that agrees reasonably well with the consensus for translation initiation (Fig. 1A) (Kozak 1984). This ORF would encode a polypeptide with a predicted $M_{r}$ of 27.9 $\mathrm{kD}$, which is approximately equivalent to the size of the primary translation product obtained following in vitro transcription and translation of the full-length MyoD1related cDNA (T. Brennan, D. Edmondson, and E. Olson, unpubl.). We notice that the sequence between nucleotides 9 and 61 in the $5^{\prime}$-untranslated region was repeated between nucleotides 561 and 613 in the coding region. The significance of this, if any, is unclear. The 5 ' end of the largest of the $\mathrm{BC}_{3} \mathrm{Hl}$ cDNAs corresponded to nucleotide 231 of the longest $\mathrm{C} 2 \mathrm{cDNA}$ and extended to the poly(A) tail. The $\mathrm{C} 2$ and $\mathrm{BC}_{3} \mathrm{H} 1$ cDNAs were identical within this 1340-bp region. Although all of the clones obtained were identical, this does not rule out the possibility that additional genes, which share homology with MyoD1, might exist within $\mathrm{BC}_{3} \mathrm{H} 1$ or $\mathrm{C} 2$ cells.

While this work was in progress, we became aware of a cDNA isolated by Wright and co-workers that also showed homology with the basic and myc domains of MyoDl (Wright et al. 1989). Their cDNA, designated myogenin, was isolated by subtraction-hybridization of cDNA from rat $\mathrm{L} 6$ myoblasts early in the differentiation program against cDNA from undifferentiated L6 myoblasts. Comparison of the sequence of the mouse MyoDl-related cDNA with the rat myogenin cDNA revealed $92 \%$ homology and indicated that they represented the same gene product. Therefore, we will refer to the MyoDl-related cDNA, hereafter, as myogenin. There are, however, some apparent differences between the mouse and rat sequences. In particular the mouse sequence encodes a protein of 246 amino acids, whereas the rat sequence encodes a protein of 287 amino acids. There are also nonconservative amino acid substitutions between the mouse and rat sequences at positions 124 , $156,158,189,234,237$, and 244.

Comparison of the sequence of the myogenin cDNA with the sequence of MyoD1 revealed 69\% homology at the nucleotide level within a region of MyoDl encompassing the basic and myc similarity domains, with limited homology outside of these domains. The basic domain also shares homology with c-myc. The homology between the MyoDl probe used for the screen and the corresponding region of the myogenin cDNA was $58 \%$; however, several stretches with greater than $90 \%$ homology were contained within the region encompassed by the probe. At the amino acid level, the homology between the two predicted sequences was $72 \%$ over the region of the myc and basic domain and, with conservative amino acid substitutions, the predicted polypeptides were $83 \%$ identical within this region (Fig. 1B). Dot

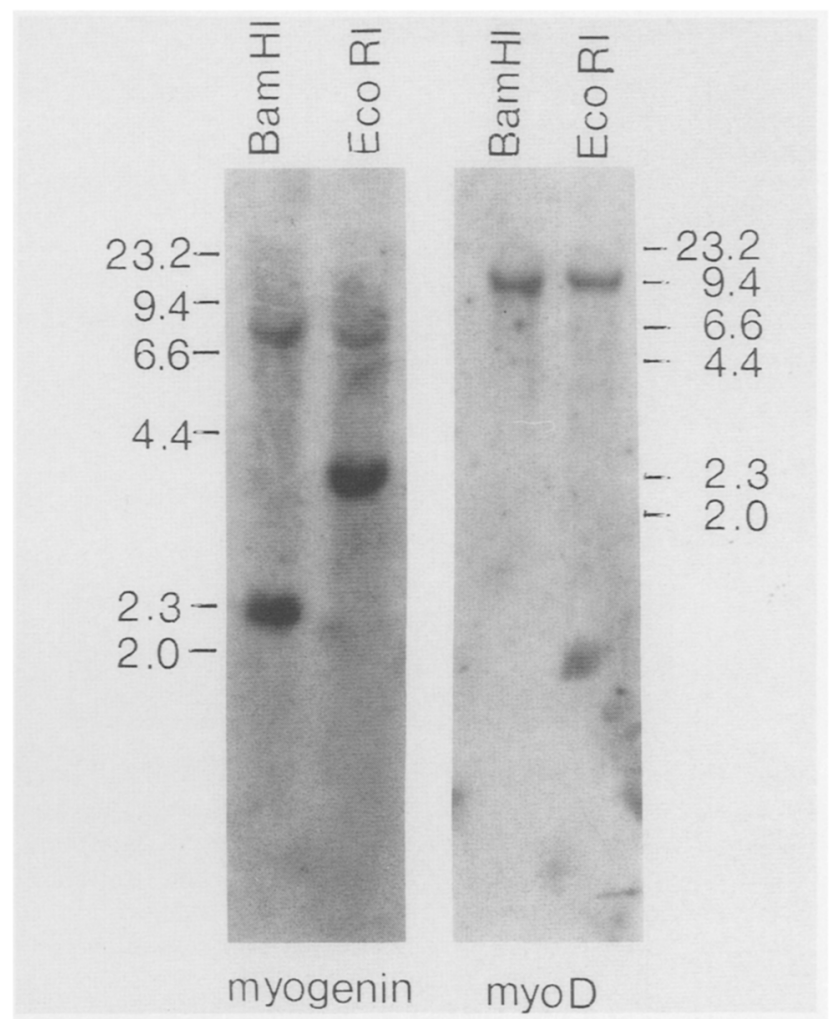

Figure 2. Southern analysis of mouse genomic DNA with myogenin and MyoD1 cDNA probes. Genomic DNA was isolated from $\mathrm{C} 2$ myoblasts, digested with EcoRI or BamHI, and electrophoresed on a $0.8 \%$ agarose gel. After transfer to nitrocellulose, blots were hybridized with the full-length myogenin and MyoDl cDNA probes. Sizes of DNA markers in kilobases are indicated.

matrix comparison of the myogenin cDNA and MyoD1 shows the relative position of the homologous segment and the extent of homology between the two cDNAs (Fig. 1C). Nucleotide mismatches dispersed throughout the myc and basic domains indicate that the myogenin mRNA does not arise by differential splicing from the MyoDl gene. Southern blot analysis of mouse genomic DNA with the myogenin and MyoD1 cDNAs confirms that these represent distinct single-copy genes (Fig. 2).

The ORF of myogenin contains several interesting domains and is remarkably similar to MyoDl, even in regions that lack strong amino acid homology. An acidic domain is found between residues 1 and 59. Although myogenin and MyoDl share only limited homology within this region, the first 60 residues of MyoDl also have been reported to comprise an acidic domain (Tapscott et al. 1988). A domain rich in cysteine and histidine, which resembles the zinc finger motif found in several DNA-binding proteins (Berg et al. 1986), is found between residues 60 and 73 . MyoD1 contains a similar Cys/His-rich region between residues 62 and 101. A basic domain is found between residues 74 and 96 . This domain lies within the region of nucleotide homology with MyoD1. Like MyoDl, myogenin also shares homology with the myc family and the Drosophila achaete-scute complex (Villares and Cabrera 1987), as 

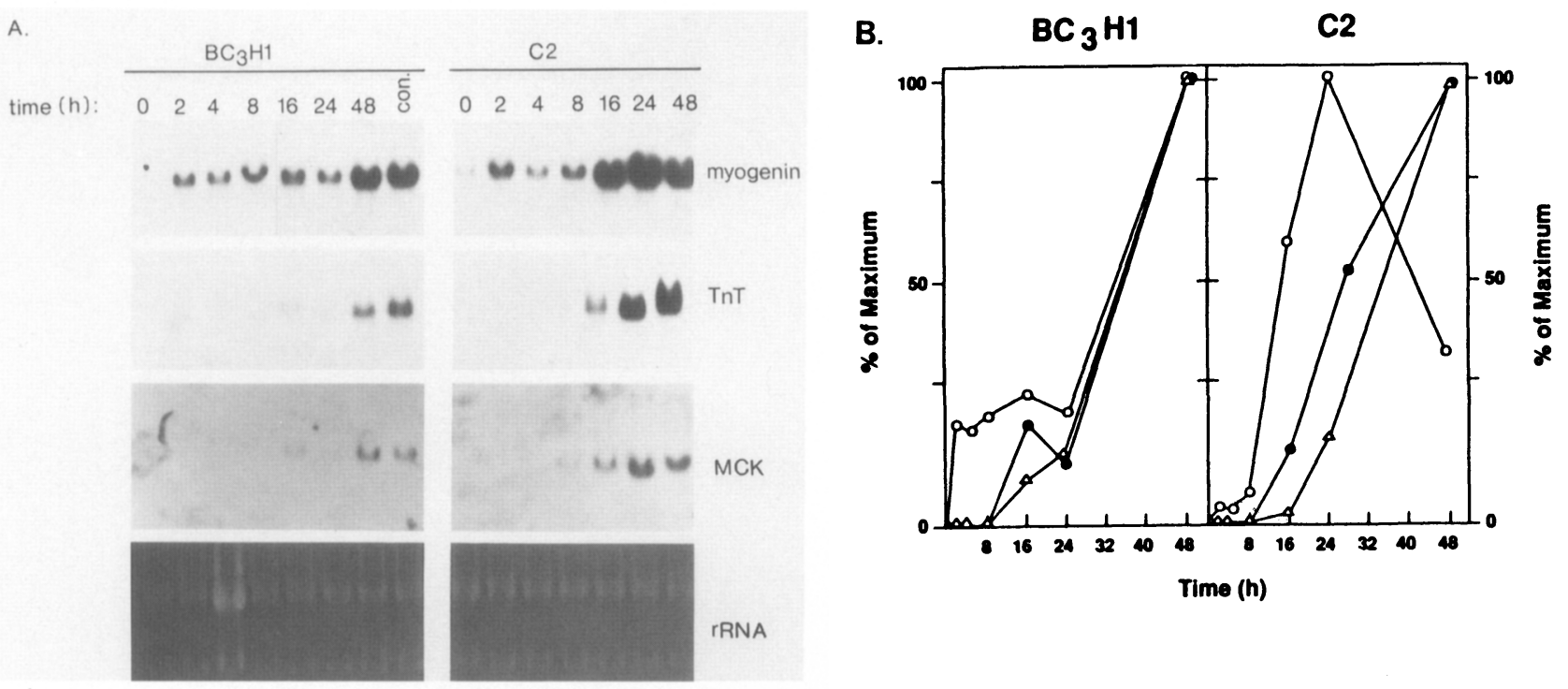

Figure 3. Northern analysis of myogenin mRNA in cell lines. Total cellular RNA was isolated from the cell lines indicated and analyzed for expression of myogenin, MCK, or Tn- $\mathrm{T}$ transcripts, as specified. $(A) \mathrm{BC}_{3} \mathrm{H} 1$ or $\mathrm{C} 2$ myoblasts were transferred from growth medium to differentiation medium for the indictated times. A set of $\mathrm{BC}_{3} \mathrm{Hl}$ cultures was also allowed to differentiate at confluency in growth medium (con). Longer exposures failed to reveal Tn-T or MCK transcripts at times earlier than $8 \mathrm{hr}$ after exposure to cells of differentiation medium (data not shown). The slight increase in myogenin RNA expression observed in $\mathrm{C} 2$ cells at $2 \mathrm{hr}$ in differentiation medium (as compared to 4 and $8 \mathrm{hr}$ ) appears to represent a variation in this particular RNA preparation. $(B)$ Relative levels of individual RNAs in $A$ were quantitated by densitometry and are expressed relative to the maximum level of expression of each RNA which was assigned a value of $100 \%$. (O) Myogenin; $(\triangle)$ MCK; (O) Tn-T. (C) $10 \mathrm{~T}^{1 / 2}, 3 \mathrm{~T} 3$, or A7r5 cells were maintained as proliferating cultures (lane $P$ ) at subconfluent densities in growth medium or as quiescent cultures (lane $Q$ ) at confluency in differentiation medium for 5 days, as indicated. The lane designated C2 contains RNA from C2 cells exposed to differentiation medium for $48 \mathrm{hr} ; 10 \mu \mathrm{g}$ of RNA was applied to each lane. Ethidium bromide staining of the gels is shown to confirm that equivalent quantities of RNA were electrophoresed on each lane.

well as the Drosophila gene daughterless (Caudy et al. 1988; Cronmiller et al. 1988), which is necessary for sex determination and formation of the peripheral nervous system. We also detected significant homology between the myc and basic regions of myogenin and the Drosophila gene twist, which is expressed in presumptive mesodermal cells and is required for germ layer formation (Thiesse et al. 1988). The amino acid sequence throughout this region appears to possess the potential to adopt a helix-loop-helix structure, as has been proposed for several other proteins that share the myc homology (Murre et al. 1989).

Myogenin mRNA is induced during myogenesis and is restricted to skeletal muscle in vivo

The pattern of expression of myogenin was examined during differentiation of $\mathrm{BC}_{3} \mathrm{H} 1$ and $\mathrm{C} 2$ cells. Myogenin

mRNA was undetectable in proliferating $\mathrm{BC}_{3} \mathrm{Hl}$ cells and was present at very low, but detectable, levels in $\mathrm{C} 2$ myoblasts at subconfluent density in mitogen-rich medium (Fig. 3A,B). Following transfer to mitogen-deficient medium, this mRNA was upregulated in both muscle cell lines within $2 \mathrm{hr}$. After 16-24 hr in mitogen-deficient medium, an additional increase in myogenin mRNA expression was observed. As reported previously, MyoD1 mRNA was undetectable in $\mathrm{BC}_{3} \mathrm{Hl}$ cells, regardless of their state of differentiation (Davis et al. 1987). MyoDl mRNA was present in C2 myoblasts and increased in abundance during differentiation (data not shown).

To establish whether myogenin mRNA was induced prior to or in parallel with other muscle-specific gene products, its kinetics of induction were compared with those of troponin- $\mathrm{T}(\mathrm{Tn}-\mathrm{T})$ and muscle creatine kinase 
(MCK). As shown in Figure 3, A and B, accumulation of the myogenin transcript preceded expression of these muscle-specific genes by several hours. Together, these results demonstrate that myogenin represents an early marker for myoblast differentiation and that its expression does not require MyoD1.

Myogenin mRNA was undetectable in proliferating or quiescent $3 \mathrm{~T} 3$ cells or $10 \mathrm{~T}^{1 / 2}$ cells (Fig. $3 \mathrm{C}$ ). In light of the reported similarities between $\mathrm{BC}_{3} \mathrm{Hl}$ cells and smooth muscle, we also examined the A7r5 smooth muscle-like cell line for the myogenin transcript, but did not detect its presence in proliferating or quiescent cells (Fig. 3C). Analysis of adult mouse tissues for expression of myogenin mRNA showed that this mRNA was restricted to skeletal muscle, with no detectable expression in heart, smooth muscle, or nonmuscle tissues (Fig. 4).

\section{The myogenin cDNA converts $10 T^{1 / 2}$ cells to myoblasts}

We investigated whether expression of myogenin was sufficient to mediate myogenic conversion by placing the cDNA under transcriptional control of a strong viral promoter and transfecting $10 \mathrm{~T}^{1 / 2}$ and $3 \mathrm{~T} 3$ fibroblasts. To allow direct comparison with MyoD1, we used the pEMSVscribe 2 expression vector used previously to characterize MyoD1 (Davis et al. 1987; Tapscott et al. 1988). The relative efficiencies of myogenin and MyoDl in myogenic conversion were tested initially by immunostaining transiently transfected cul-

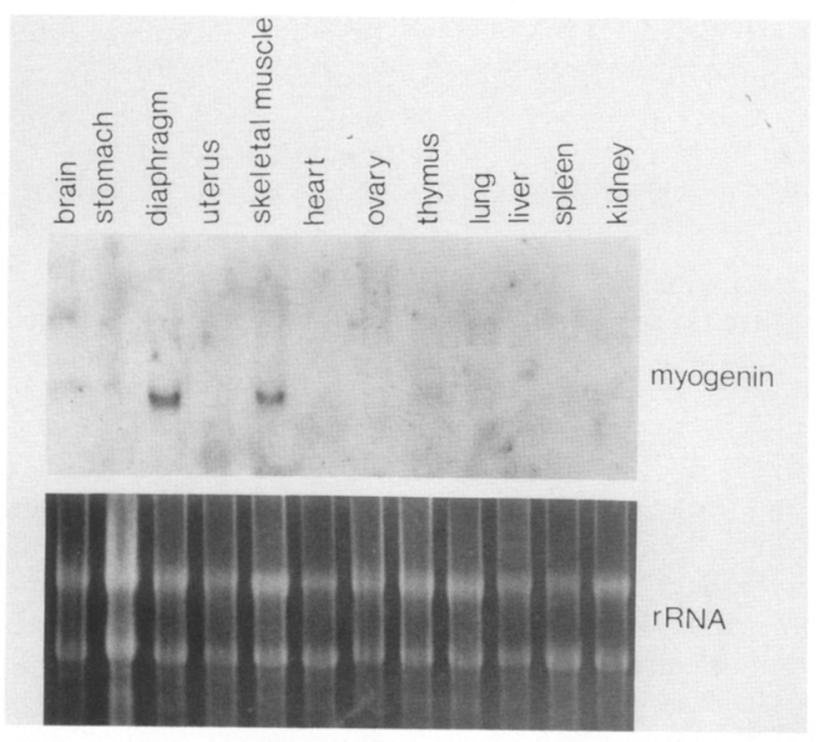

Figure 4. Northern analysis of myogenin mRNA in mouse tissues. RNA was isolated from the indicated tissues of adult mice and subjected to Northern analysis using a labeled myogenin probe; $10 \mu \mathrm{g}$ of RNA was applied to each lane. Ethidium bromide staining of the gels is shown to confirm that equivalent quantities of RNA were electrophoresed on each lane. The faint bands which are detectable in RNA from brain appear to represent nonspecific hybridization to $18 \mathrm{~S}$ and $28 \mathrm{~S}$ ribosomal RNAs.

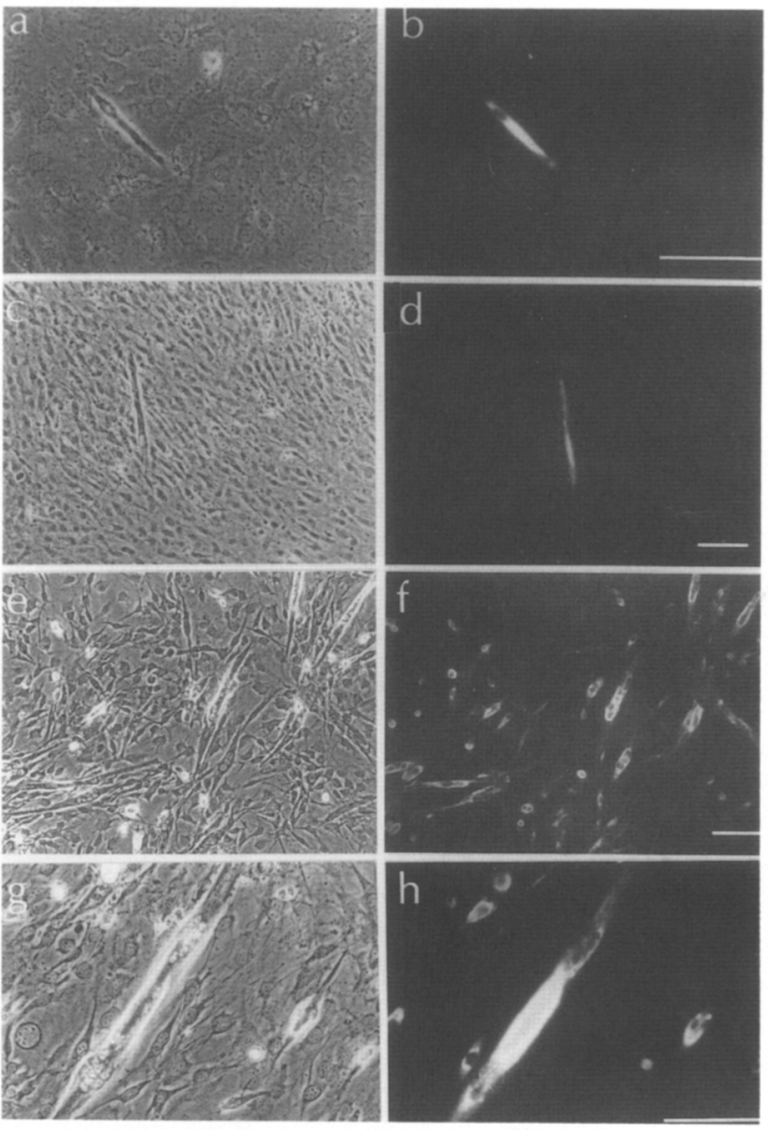

Figure 5. Myosin immunostaining of $3 \mathrm{~T} 3$ and $10 \mathrm{~T}^{1 / 2}$ cells following transfection with the myogenin cDNA expression vector. Cultures of $3 \mathrm{~T}^{3}$ cells $(a$ and $b)$ or $10 \mathrm{~T}^{1} / 2$ cells $(c-h)$ were transfected with the myogenin cDNA expression vector. $(a-d)$ Results of transient transfections; $(e-h)$ stably transfected clone. Following transfection, cultures were maintained in growth medium for $48 \mathrm{hr}$. For transient transfections, cultures were then transferred to differentiation medium for 3 days. Stable transfections were carried out with pSV2neo as a dominant selectable marker. G-418 was added to cultures $48 \mathrm{hr}$ after transfection and cultures were maintained in selection medium for 14 days, at which time they were transferred to differentiation medium for 4 days. After exposure to differentitation medium, cultures were fixed and stained with anti-myosin heavychain antibody, MF-20, as described in Materials and methods. $(a, c, e$, and $g)$ Phase-contrast photomicrographs; $(b, d, f$, and $h)$ immunofluorescent photomicrographs. Bar, $100 \mu \mathrm{m}$. Frequencies for conversion for myosin-positive cells are shown in Table 1.

tures with a myosin heavy-chain antibody. As shown in Figure $5, a-d$, exposure of transiently transfected $3 \mathrm{~T} 3$ or $10 \mathrm{~T}^{\mathrm{L}} / 2$ cells to mitogen-deficient medium for 3 days led to the appearance of myosin-positive cells, which were generally distinguishable morphologically by their elongated appearance compared to surrounding cells. The frequency of myosin-positive cells observed with this assay is summarized in Table 1 . The results showed that the myogenin cDNA gave rise to myosin-positive cells with a frequency about two- to fourfold lower than MyoDl (Table 1). The efficiency of myogenic conversion 
Table 1. Frequency of myosin-positive cells following transient transfection with the myogenin expression vector

\begin{tabular}{lcc}
\hline Expression & \multicolumn{2}{c}{ Frequency of myogenic conversion } \\
\cline { 2 - 3 } vector & $10 \mathrm{~T} 1 / 2$ & $3 \mathrm{~T} 3$ \\
\hline Myogenin & $1.2 \times 10^{-4}$ & $1.1 \times 10^{-5}$ \\
MyoD1 & $2.7 \times 10^{-4}$ & $4.4 \times 10^{-5}$ \\
\hline
\end{tabular}

Cultures of $10 \mathrm{~T}^{1 / 2}$ and $3 \mathrm{~T} 3$ cells were transfected transiently with $10 \mu \mathrm{g}$ of the indicated cDNA in the vector pEMSVscribe $\alpha 2$. Forty-eight hours later, cultures were transferred to differentiation medium. After 4 days, cultures were fixed and stained with anti-myosin antibody as described in Materials and methods. Cells transfected with antisense myogenin cDNA showed no myogenic conversion. Frequencies were determined by inspection of between 1 and $2 \times 10^{7}$ cells.

was nearly an order or magnitude higher in $10 \mathrm{~T}^{1 / 2}$ cells compared with $3 \mathrm{~T} 3$ cells.

We also examined the ability of the myogenin cDNA to convert $10 \mathrm{~T}^{1 / 2}$ cells to myoblasts following stable transfection. 10T $1 / 2$ cells stably transfected with the myogenin cDNA and pSV2neo as a dominant selectable marker proliferated and failed to express the skeletal muscle phenotype when maintained at subconfluent densities in mitogen-rich medium. After transfer to mitogen-deficient medium, stable clones that formed myotubes and stained with the anti-myosin antibody were observed. We observed no myogenic clones following transfection with the expression vector lacking an insert or with myogenin in the antisense orientation. A representative myogenic clone generated by transfection with the myogenin cDNA is shown in Figure 5, e-h. Multinucleate myotubes that are myosin-positive are readily apparent throughout this clone. Within individual myogenic clones, we observed highly differentiated cells, in addition to cells that neither fused nor stained for myosin heavy chain. This heterogeneity was maintained when these clones were expanded into cell lines. Similar observations were reported previously for MyoD1 and myd transfectants (Davis et al. 1987; Pinney et al. 1988). Since all cells within a given colony are clonal, this may suggest that there is a threshold of myogenin expression that is required for activation of the differentiation program and that cells within a clonal population exhibit a distribution in the level of myogenin expression. We plan to address this question using an antibody against myogenin to quantitate levels of myogenin expression at the single-cell level.

Representative myogenic clones obtained following transfection of $10 \mathrm{~T}^{1 / 2}$ cells with the myogenin cDNA were passaged into stable cell lines and analyzed for expression of the myogenin transcript, as well as other muscle-specific mRNAs. The clone shown in Figure 6, designated 10TFL4, constitutively expressed myogenin at subconfluent density in mitogen-rich medium. The rate of cell division of mitogen-rich medium was similar in myogenin-transfectants and transfectants harboring only the neomycin-resistance gene. Following transfer to fusion-promoting medium, myogenin mRNA increased approximately 10 -fold. Preliminary results indicate that this increase in myogenin expression upon re-

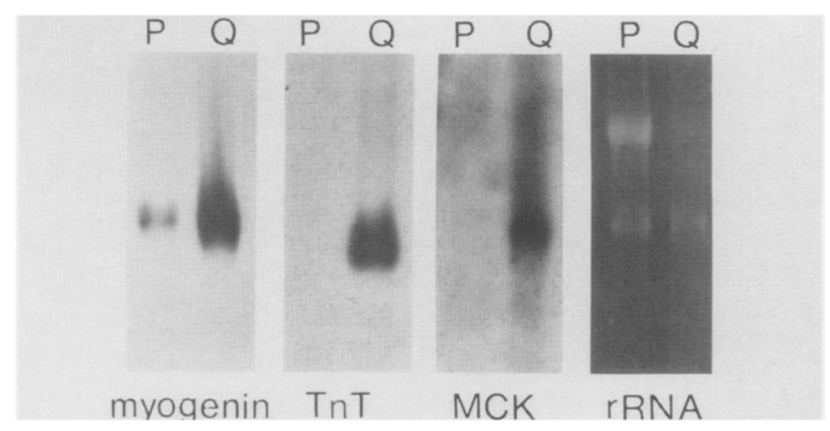

Figure 6. Expression of myogenin and muscle-specific mRNAs in $10 \mathrm{~T}^{1 / 2}$ cells stably transfected with the myogenin cDNA expression vector. A representative clone of $10 \mathrm{~T}^{1 / 2}$ cells, denoted 10TFL4, stably transfected with the myogenin cDNA and pSV2neo as a dominant selectable marker, was isolated and passaged into a stable cell line. Total cellular RNA, isolated from proliferating cultures (lane $P$ ) at subconfluent density in growth medium and from quiescent cultures (lane $Q$ ) at confluency in differentiation medium, was analyzed by Northern analysis for expression of myogenin, MCK, and Tn-T mRNAs, as specified. Ten micrograms of RNA was applied to each lane.

moval of mitogens is due to activation of the endogenous myogenin gene (D. Edmondson and E. Olson, in prep.). Tn-T and MCK mRNAs were undetectable in proliferating 10TFL4 cells, but were induced to high levels following transfer of this cell line to fusion-promoting medium. Similar results were obtained with multiple clones of $10 \mathrm{~T}^{1 / 2}$ cells harboring the myogenin expression vector (data not shown). Together, these results show that upon removal of mitogens, the myogenin cDNA leads, either directly or indirectly, to fusion and activation of multiple muscle-specific genes.

\section{The myogenin cDNA activates a muscle-specific enhancer upstream from the mck gene following transient transfection into nonmyogenic cells}

Developmental regulation and muscle-specific expression of the mck gene has been shown to be dependent on an upstream muscle-specific enhancer located between -1204 and -1048 bp relative to the transcription initiation site (Jaynes et al. 1988; Sternberg et al. 1988, 1989). This enhancer is inactive in myoblasts and nonmyogenic cells and directs high levels of transcription from the mck promoter or from heterologous promoters in myotubes. To test whether the myogenin cDNA was able to activate the mck $5^{\prime}$ enhancer, 10T $1 / 2$ cells were cotransfected with the myogenin cDNA expression vector and a reporter gene (cat) under transcriptional control of a series of mck 5' sequences or viral control elements. As shown in Figure 7, cotransfection of the myogenin cDNA and pCK4800CAT, which contains the $4.8 \mathrm{~kb}$ of DNA immediately preceding the mck gene, led to significant levels of CAT expression in $10 \mathrm{~T}^{1 / 2}$ cells. In contrast, CAT expression was undetectable following cotransfection of pCK4800CAT with the myogenin cDNA in the antisense orientation. To begin to define the DNA sequences responsible for myogenin-dependent activation of the mck-cat gene, we examined the 

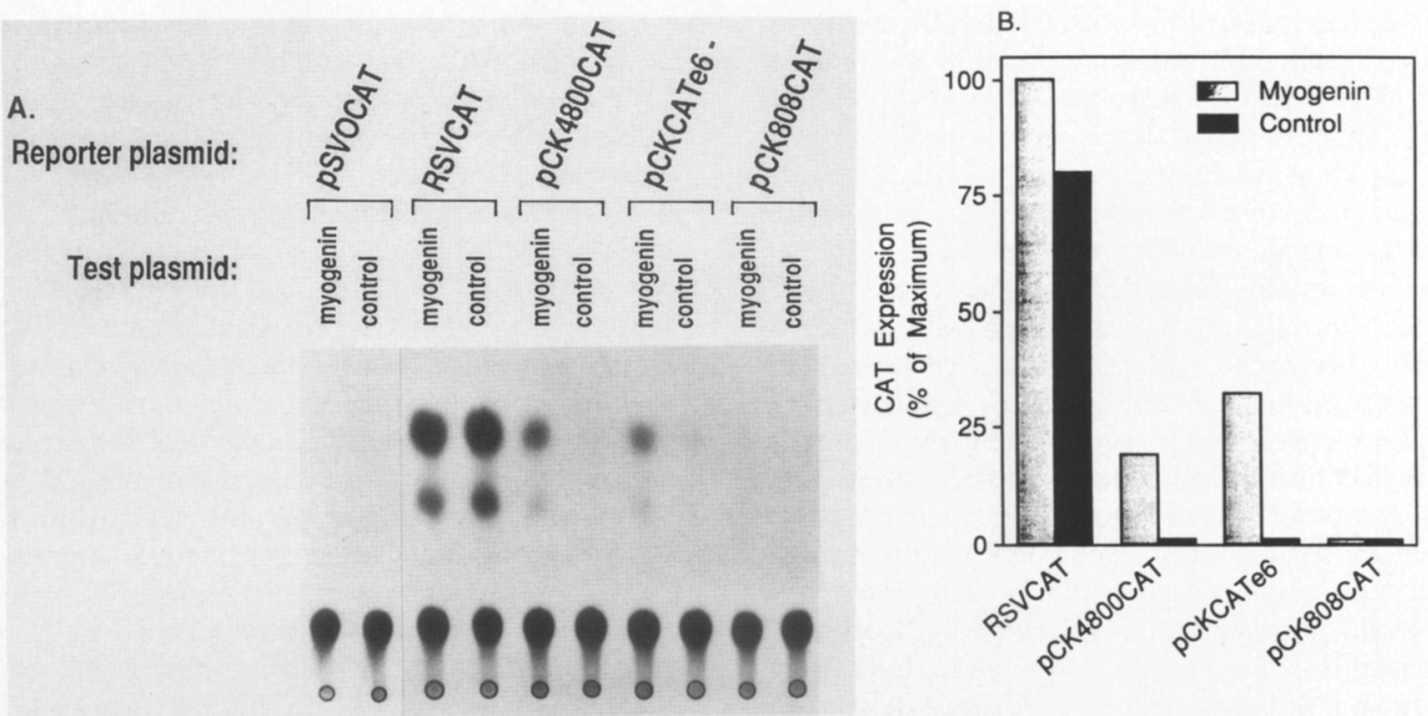

Figure 7. CAT activity in $10 \mathrm{~T}^{1 / 2}$ cells transiently transfected with the myogenin cDNA expression vector and mck-cat reporter genes. 10T $1 / 2$ cells were transfected transiently with $10 \mu \mathrm{g}$ of each of the indicated reporter plasmids and $2 \mu \mathrm{g}$ of test plasmids. At $48 \mathrm{hr}$ following transfection, cultures were transferred to differentiation medium for $96 \mathrm{hr}$. Cells were then harvested and levels of CAT activity were determined as described in the text. $(A)$ Thin-layer chromatographs of a representative CAT assay. $(B)$ Results from several assays were quantitated and are expressed relative to the level of CAT activity in 10T1/2 cells transfected with RSV-CAT and the myogenin expression vector in the sense orientation, which was assigned a value of $100 \%$. Control refers to transfectons with the indicated CAT vectors and the expression vector with myogenin in the antisense orientation. Cotransfections using pUC19 as a control yielded comparable results.

ability of myogenin to activate expression of pCK808CAT, which contains only the mck promoter, and pCKCATe6-, which contains the promoter plus the 156-bp enhancer shown to be responsible for musclespecific activity. The detailed structures of these plasmids are described in Materials and methods. Myogenin showed little or no effect on pCK808CAT, whereas it directed expression of pCKCATe6- at a level approximately equivalent to pCK4800CAT (Fig. 7). These results suggest that the upstream enhancer mediates the actions of myogenin on the mck gene. The magnitude of induction of the mck enhancer by myogenin exceeds 20 -fold, but is difficult to quantitate absolutely because there is no detectable expression in $10 \mathrm{~T}^{1 / 2}$ cells in the absence of the myogenin expression vehicle. We reproducibly observed a weak positive effect of the myogenin cDNA on expression of RSVCAT (Fig. 7) and a two- to fourfold stimulation of pSV2CAT (data not shown). Whether this reflects a generalized effect on several enhancers or a specific interaction with elements that may be shared between the SV40, RSV, and mck enhancers remains to be determined. Together, these results demonstrate that myogenin can function, either directly or indirectly, as a trans-activator of muscle-specific regulatory elements associated with the mck gene.

\section{Discussion}

Identification of a MyoD1-related gene that is induced early in the myogenic differentiation program

MyoDl is expressed exclusively in skeletal muscle in vivo and in vitro and exhibits the ability to convert a variety of cells of mesodermal origin to myoblasts. Deletion mutagenesis has revealed that a 68-amino-acid segment encompassing the basic and myc-similarity domains of MyoDl is both necessary and sufficient for MyoD1-dependent conversion of fibroblasts to the myogenic lineage (Tapscott et al. 1988). The apparent importance of the myc domain as a positive effector for myogenic conversion led us to examine whether the $\mathrm{BC}_{3} \mathrm{H} 1$ muscle cell line, which does not express MyoDl at detectable levels, might express a functionally equivalent regulatory gene product. Screening of a $\mathrm{BC}_{3} \mathrm{Hl} \mathrm{cDNA}$ library at low stringency with a region of the MyoDl cDNA corresponding to the myc domain resulted in the identification of a MyoD1-related cDNA. The deduced MyoD1-related polypeptide exhibits $72 \%$ homology to MyoD1 over the basic and myc regions and only limited homology outside of these regions. Within the 68amino-acid segment of MyoDl defined as the critical region for myogenic conversion, the two proteins are identical at 49 residues and with conservative substitutions are conserved over 54 residues. The organization of domains within the two predicted polypeptides is also remarkably similar, even over regions that lack strong amino acid homology. The rat homolog of this MyoD1related cDNA was cloned independently by Wright and co-workers using subtraction hybridization, and has been designated myogenin (Wright et al. 1989).

\section{Myogenin expression is sufficient to activate the muscle differentiation program}

In addition to the structural similarities between MyoD1 and myogenin, these gene products exhibit func- 
tional similarities in that they both possess the ability to activate the muscle differentiation program in nonmyogenic cells. Although myogenin and MyoDl might activate muscle-specific genes directly, an alternate possibility is that they modulate a set of regulatory gene products that may, in turn, modulate expression of the genes that are activated during myogenesis. To begin to define the mechanisms that allow muscle-specific genes to respond to myogenin, we examined whether myogenin would direct the expression of a reporter gene under transcriptional control of mck regulatory sequences. These experiments revealed that the 156-bp 5' enhancer region of mck was necessary and sufficient to confer myogenin-dependent regulation on the mck promoter. This 156-bp region has been demonstrated to interact with three nuclear factors that are expressed with kinetics similar to myogenin in $\mathrm{C} 2$ and $\mathrm{BC}_{3} \mathrm{Hl}$ cells following a stimulus to differentiate (D. Kelvin, L. Gossett, E. Sternberg, and E. Olson, in prep.). A myocyte-specific factor that interacts with this region has also been identified in nuclear extracts from mouse MM14 myotubes (J. Buskin and S. Hauschka, in press). Studies are in progress to determine whether any of these enhancer-binding factors may represent myogenin. In this regard, Murre et al. have recently identified two cDNAs whose products show homology to the basic and myc domain of myogenin. These factors bind specifically to the KE2 motif of the immunoglobulin $\kappa$-chain enhancer through a mechanism dependent on this domain (Murre et al. 1989). Because an element has been identified within the mck enhancer that shares 12 of 14 nucleotides with the KE2 motif, it is plausible that myogenin may interact directly with the mck enhancer at this site (Jaynes et al. 1988; Sternberg et al. 1988).

Although it is clear that constitutive expression of myogenin can direct the expression of muscle-specific genes in nonmyogenic cells, it is important to emphasize that the activity of myogenin is modulated in a negative manner by mitogens. This was demonstrated most clearly by stable transfection of $10 \mathrm{~T}^{1 / 2}$ cells with the myogenin expression vector. In the presence of high levels of mitogens, these cells expressed the transfected myogenin gene, but did not express muscle-specific gene products. It appears, therefore, that myogenin, which is normally expressed at high levels in $\mathrm{C} 2$ and $\mathrm{BC}_{3} \mathrm{Hl}$ cells only after withdrawal of mitogens, may play an important role in a transcriptional regulatory program that is antagonized by mitogenic signals.

\section{Interactions between myogenic regulatory genes}

It is interesting to consider the potential relationship between myogenin, MyoD1, and myd. Southern blot analysis of myd transfectants with a myogenin cDNA indicates that myd and myogenin represent distinct genetic loci (C.P. Emerson, pers. comm.). Whereas myd is postulated to mediate the initial conversion of stem cells to the myogenic pathway and would therefore be expected to be expressed in myoblasts (Pinney et al. 1988), the temporal pattern of myogenin expression, combined with its ability to activate the differentiation program, suggests that this gene product may function as a differentiation-specific transcription factor that controls multiple muscle-specific genes. Thus, myogenin may be required toward the end of a myogenic regulatory pathway.

The relative positions of MyoDl and myogenin in the hypothetical hierarchy of myogenic regulatory genes are more equivocal and may vary in different myogenic cell types or developmental situations. Because $\mathrm{BC}_{3} \mathrm{Hl}$ cells do not express MyoDl at detectable levels, we conclude that neither myogenin nor other muscle-specific genes are absolutely dependent on MyoD1 for expression. An attractive hypothesis is that the structural differences between myogenin and MyoDl may allow these proteins to interact with different cellular factors or DNA sequences and thereby modulate parallel or interacting regulatory pathways. In this regard, the transfection assays that have been used to analyze the functions of these genes seem to require high levels of expression of the cDNAs to observe myogenic conversion and, as a result, might lead to a loss of subtle specificities that might be observed at more physiological levels of these gene products. It is important to emphasize that expression of these regulatory factors is not mutually exclusive, because differentiated $\mathrm{C} 2$ cells and, more importantly, muscle tissue express both myogenin and MyoDl. Thus, both of these regulatory factors may be required in vivo to express the full myogenic phenotype properly.

\section{$B C_{3} H 1$ cells may represent a fusion-defective skeletal muscle line}

The classification of $\mathrm{BC}_{3} \mathrm{Hl}$ cells as skeletal or smooth muscle has been controversial. This cell line, which was isolated from a nitrosoethylurea-induced brain tumor (Schubert et al. 1974), expresses a broad array of genes specific to skeletal muscle; however, they do not fuse or commit irreversibly to the postmitotic state in mitogendeficient medium (Munson et al. 1982; Olson et al. 1983, 1984, 1986; Spizz et al. 1986; Hu and Olson 1988; Lathrop et al. 1985). These aspects of the $\mathrm{BC}_{3} \mathrm{H} 1$ differentiation program have contributed to speculation about the embryonic origin of these cells as well as their precise classification as smooth or skeletal muscle. The observation that myogenin is restricted to skeletal muscle in vivo and in vitro, and is undetectable in smooth muscle tissue or in the $\mathrm{A} 7 \mathrm{r} 5$ smooth muscle-like cell line, suggests that $\mathrm{BC}_{3} \mathrm{Hl}$ cells represent a line of skeletal muscle origin. The reported expression of smooth muscle $\alpha$-actin by $\mathrm{BC}_{3} \mathrm{H} 1$ cells (Strauch and Rubinstein 1984; Strauch et al. 1986) is not inconsistent with a skeletal muscle phenotype, as other skeletal muscle cells appear to express this actin isoform (Buckingham et al. 1982; Pinset and Whalen 1984). Because myogenin expression in $10 \mathrm{~T}^{1 / 2}$ cells can lead to fusion, the inability of $\mathrm{BC}_{3} \mathrm{H} 1$ cells to fuse or commit to terminal differentiation may be attributable to a defect in a regulatory pathway under the control of myogenin or to the lack of one or more factors that cooperate with myogenin to control these events. The fact that myogenin is ex- 
pressed at high levels in $\mathrm{BC}_{3} \mathrm{H} 1$ myocytes, which retain the ability to reenter the cell cycle in response to mitogenic stimulation, also suggests that myogenin expression alone is insufficient to confer the postmitotic state.

\section{Potential interactions between $c$-myc and members of the MyoD1 family}

There is considerable evidence to suggest that c-myc plays a critical role in the control of differentiation of diverse cell types (Coppola and Cole 1986; Dmitrovsky et al. 1986; Prochownik and Kukowska 1986; Cole 1987). In myoblasts, for example, expression of c-myc declines dramatically prior to the onset of differentiation (Endo and Nadal-Ginard 1986; Spizz et al. 1987). Conversely, growth factors that suppress myogenic differentiation induce c-myc expression, and certain differentiation-defective muscle cell lines fail to downregulate c-myc following exposure to mitogen-deficient medium (Sejersen 1985; Olson et al. 1987; Payne et al. 1987; Spizz et al. 1987). The potential involvement of c-myc as a negative regulator of differentiation is suggested further by the ability of deregulated c-myc alleles or of $\mathrm{v}-m y c$ to disrupt the differentiation program of a variety of cell types including myoblasts (Falcone et al. 1985; Coppola and Cole 1986; Dmitrovsky et al. 1986; Prochownik and Kukowska 1986; Denis et al. 1987; Schneider et al. 1987). Considering the homology between c-myc and myogenin/MyoD1, it is tempting to speculate that myc may compete with these myogenic regulatory factors for interaction with critical cellular targets. Within this context, the inability of $\mathrm{c}-m y c$ to abolish the induction of muscle-specific genes in $\mathrm{BC}_{3} \mathrm{H} 1$ cells (Schneider et al. 1987) or to suppress muscle-specific genes in L6E9 myotubes (Endo and Nadal-Ginard 1986) may indicate that the level of myc expression cannot reach a sufficient level to counterbalance the positive influences of myogenin or MyoDl on myogenesis.

The presence of the myc homology in multiple genes that function as positive effectors for cellular determination and differentiation supports the prediction of Davis et al. (1987) that the myc-like motif may represent a specialized protein domain common to multiple regulatory factors. In the future, it will be interesting to identify additional genes that share this conserved motif and ultimately to identify the cellular targets with which they interact.

\section{Materials and methods}

\section{Cell culture}

$\mathrm{BC}_{3} \mathrm{H1}$ (Schubert et al. 1974) and C2 (Yaffe and Saxel 1977) cells were maintained at subconfluent densities in growth medium containing Dulbecco's modified eagle's medium (DMEM) with $20 \%$ fetal bovine serum (FBS) and were split every $48-72 \mathrm{hr}$ to ensure that the cells did not make extensive cell-cell contact. To initiate differentiation, $\mathrm{BC}_{3} \mathrm{Hl}$ cells were transferred to DMEM with $0.5 \%$ FBS and C2 cells were exposed to DMEM with a $2 \%$ horse serum (differentiation media). C3H10T $1 / 2$,
NIH-3T3, and A7r5 cells (Kimes and Brandt 1976) were maintained in DMEM with 20\% FBS unless otherwise specified.

\section{Screening cDNA libraries}

Oligo(dT)-primed cDNA libraries were prepared from the poly $(\mathrm{A})^{+}$mRNA of $\mathrm{C} 2$ myotubes or $\mathrm{BC}_{3} \mathrm{Hl}$ myocytes in the $\lambda$ ZAP phage (Stratagene). Initial identification of MyoDl-related cDNAs were performed by hybridization of $\sim 200,000$ phage plaques from each library at a density of 10,000 plaques $/ 15-\mathrm{cm}$ dish with a DdeI fragment from mouse MyoD1 (Davis et al. 1987). This region of MyoDl encompasses the basic and myc domains as defined by Davis et al. (1987). After hybridization at $42^{\circ} \mathrm{C}$ for $16 \mathrm{hr}$ in $35 \%$ formamide, $5 \times$ SSC $(1 \times$ SSC is $0.15 \mathrm{M}$ $\mathrm{NaCl}$ plus $0.015 \mathrm{M}$ sodium citrate), $5 \times$ Denhardt's solution, 50 mM sodium phosphate, and $10 \%$ dextran sulfate, filters were washed for $60 \mathrm{~min}$ at room temperature and for $30 \mathrm{~min}$ at $55^{\circ} \mathrm{C}$ in $2 \times$ SSC, $0.1 \%$ SDS. Positive clones were plaque-purified, and clones that hybridized to the MyoDl probe at reduced stringency, but not at high stringency, were analyzed by restriction mapping. Clones obtained from low-stringency screens were used to rescreen the $\mathrm{BC}_{3} \mathrm{H} 1$ and $\mathrm{C} 2$ libraries at high stringency to obtain additional cDNAs.

\section{RNA isolation and Northern analysis}

Total cellular RNA was isolated from cells and tissues by the guanidinium method (Chomczynski and Sacchi 1987). RNA was electrophoresed on formaldehyde-agarose gels, transferred to nitrocellulose, and hybridized to labeled DNA probes as described (Spizz et al. 1986). Probes were labeled with ${ }^{32} \mathrm{P}$ to a specific activity of $1-5 \times 10^{9} \mathrm{cpm} / \mu \mathrm{g}$ as described by Feinberg and Vogelstein (1983). The following probes were used: $m c k$, a 775-bp SmaI-PvuI fragment of a canine mck cDNA (Roman et al. 1985); Tn-T, 800-bp PstI fragment from a rat Tn-T clone (Garfinkel et al. 1982); myogenin, an EcoRI fragment from the coding region of the myogenin cDNA. Blots were exposed to Kodak XAR film at $-70^{\circ} \mathrm{C}$ with intensifying screens. For quantitation of mRNAs, films were exposed for periods during which band intensity was linear with respect to time. Films were then scanned with a densitometer, and mRNA abundance was determined from the area under the peak corresponding to individual mRNAs. Hybridization of cDNA probes to total cellular RNA was linear with respect to RNA concentration.

\section{Southern analysis}

Genomic DNA was extracted from C2 cells as described (Maniatis et al. 1982), digested with the indicated restriction enzymes, and electrophoresed on $0.8 \%$ agarose gels. Following transfer to nitrocellulose, DNA was hybridized to labeled probes as described above. Myogenin and MyoD1 sequences were detected using the full-length cDNAs. After hybridization, blots were washed at $68^{\circ} \mathrm{C}$ for $30 \mathrm{~min}$ in $0.1 \times \mathrm{SSC}, 0.1 \%$ SDS.

\section{DNA sequence analysis}

Putative MyoDl-related phage clones were converted to the plasmid form by the plasmid rescue procedure (Stratagene Catalog) and were sequenced using the Sequenase Sequencing Kit (United States Biochemical Company). The universal and reverse sequencing primers were used to sequence the ends of the cDNAs, and oligonucleotides corresponding to determined sequences were synthesized and used to obtain the complete sequence of the MyoD1-related cDNAs. The sequence of the ORF 
was determined for multiple cDNAs isolated from the $\mathrm{C} 2$ and $\mathrm{BC}_{3} \mathrm{Hl}$ libraries. Because of the discrepancy in the position of the stop codon in the mouse and rat sequences, two separate cDNAs from the $\mathrm{BC}_{3} \mathrm{H1}$ library and one cDNA from the $\mathrm{C} 2$ library were sequenced on both strands in the region containing the stop codon. All sequences were in agreement. Dot matrix analysis was performed using the Microgenie System for sequence analysis with a window setting of 20 nucleotides at $75 \%$ homology.

\section{Construction of expression vectors and stable transfections}

To express the myogenin cDNA, the full-length cDNA was excised from the EcoRI site of the $\lambda$ ZAP plasmid by partial digestion with EcoRI and was cloned into the $E c o R I$ site of the vector pEMSVscribe, described by Davis et al. (1987). For comparison to $\mathrm{MyoD1}$, the MyoD expression vector, EMC11s, was provided by $A$. Lassar. For stable transfections, $10 \mu \mathrm{g}$ of the appropriate expression vector was mixed with $1 \mu \mathrm{g}$ of pSV2neo as a dominant selectable marker. Transfections were performed as described above except that cultures were transferred to growth medium with G-418 $(400 \mu \mathrm{g} / \mathrm{ml}) 2$ days after transfection. Fourteen days later, stable clones were exposed to differentiation medium. After an additional 4 days, clones were analyzed for the extent of fusion and for myosin immunostaining. At the same time, clones were picked and passaged into stable cell lines.

\section{Immunostaining}

Myosin immunostaining was performed by fixing cultures in $70 \%$ ethanol, $3.7 \%$ formaldehyde, $5 \%$ acetic acid for $5 \mathrm{~min}$. Cultures were washed extensively with phosphate-buffered saline, and incubated overnight at $4^{\circ} \mathrm{C}$ with the anti-myosin antibody, MF-20 (Bader et al. 1982). After washing to remove unbound antibody, cultures were incubated sequentially with biotinylated goat anti-mouse IgG, and fluoresceine-labeled avidin.

\section{CAT assays}

The construction and properties of $m c k-c a t$ vectors have been described previously. Briefly, pCK4800CAT and pCK808CAT contain the 4800 and 808 bp, respectively, of DNA that precedes the transcription start site of the mck gene linked immediately upstream of cat in the vector pSVOCAT (Sternberg et al. 1988). The vector pCKCATe6- was constructed by insertion of an AvaI-BamHI fragment, extending from bp - 1204 to -1048 of mck, into the unique BamHI site of pCK246CAT, which contains the mck promoter region (mck -246 to +1$)$ linked immediately upstream of cat. RSV-CAT contains the cat gene under transcriptional control of the RSV long terminal repeat (Gorman et al. 1982).

Subconfluent cultures of $10 \mathrm{~T}^{1 / 2}$ or $3 \mathrm{~T} 3$ cells were transfected by calcium phosphate precipitation as described /Graham and VanderEb 1973), with $10 \mu \mathrm{g}$ of cat reporter genes and $2 \mu \mathrm{g}$ of plasmids that were tested for their ability to trans-activate mck 5 ' sequences. At $4 \mathrm{hr}$ after transfection, medium was removed and cultures were rinsed with DMEM and refed with growth medium. Two days later, cultures were exposed to differentiation medium for an additional 2 days. Cells were then harvested, and CAT activity was determined as described (Sternberg et al. 1988). All transfections were performed on at least three separate sets of cultures with at least two different DNA preparations of each plasmid. Levels of CAT activity were quantitated by excising the regions of the thin-layer chromatographs corresponding to chloramphenicol and it acetylated de- rivatives followed by scintillation counting. CAT activity in cell extracts was linear with respect to the concentration of plasmid used in the transfection and with respect to the amount of cell extract used in the assay.

\section{Acknowledgments}

This work was supported by a grant from the American Cancer Society and an Institutional Research Grant. E.N.O. is an Established Investigator of the American Heart Association. We are grateful to A. Lassar for providing us with the MyoDl plasmid and the pEMSVscribe expression vehicle and for many helpful discussions; to Donald Fischman for the MF-20 antibody; and to W. Wright for communicating results prior to publication and for helpful discussions; and to C. Murre, D. Baltimore, J. Buskin, and S. Hauschka for providing preprints of their papers; and to E. Sternberg for preparing the mck-CAT expression vectors. We also thank $M$. Perry for assistance in computer analysis of DNA sequences, Mary E. Perry for technical assistance, D. Tuchsen for tissue culture, and Ellen Madson for preparation of the manuscript.

\section{References}

Armelin, H.A., M.C.S. Armelin, K. Kelly, T. Stewart, P. Leder, B.H. Cochran, and C.D. Stiles. 1984. A functional role for c-myc in the mitogenic response to platelet-derived growth factor. Nature 310: 665-660.

Bader, D., T. Masaki, and D.A. Fischman. 1982. Immunochemical analysis of myosin heavy chain during avian myogensis in vivo and in vitro. $J$. Cell Biol. 95: 763-770.

Barbacid, M. 1987. ras genes. Annu. Rev. Biochem. 56: 779828.

Berg, J.M. 1986. Potential metal-binding domains in nucleic acid binding proteins. Science 232: 485-487.

Blau, H.M., C.P. Chiu, and C. Webster. 1983. Cytoplasmic activation of human nuclear genes in stable heterokaryons. Cell 32: $1171-1180$.

Blau, H.M., G.K. Pavlath, E.C. Hardeman, C.P. Chiu, L. Silberstein, and S.G. Webster. 1985. Plasticity of the differentiated state. Science 230: 758-766.

Buckingham, M.E., A.J. Minty, B. Robert, S. Alonso, A. Cohen, P. Daubas, A. Weydert, and M. Caravatti. 1982. Messengers coding for myosins and actins: Their accumulation during terminal differentiation of a mouse muscle cell line. In Muscle development (ed. M.L. Pearson and H.F. Epstein), pp. 210-213. Cold Spring Harbor Laboratory, Cold Spring Harbor, New York.

Caffrey, J.M., A.M. Brown, and M.D. Schneider. 1987. Mitogens and oncogenes can block the formation of specific voltagegated ion channels. Science 236: 570-574.

Caudy, M., H. Vassin, M. Brand, R. Tuma, L. Y. Jan, and Y.N. Jan. 1988. daughterless a Drosophila gene essential for both neurogenesis and sex determinatoin, has sequence similarities to myc and the achaete-scute complex. Cell 55: 10611067.

Chomczynski, P. and N. Sacchi. 1987. Single-step method of RNA isolation by acid guanidinium thiocyanate-phenolchloroform extraction. Anal. Biochem. 162: 156-159.

Clegg, C.H., T.A. Linkhart, B.B. Olwin, and S.D. Hauschka. 1987. Growth factor control of skeletal muscle differentiation: Commitment to terminal differentiation occurs in G1 phase and is repressed by fibroblast growth factor. J. Cell Biol. 105: 949-956.

Cole, M.D. 1987. The myc oncogene: Its role in transformation and differentiation. Annu. Rev. Genet. 20: 361-384. 
Coppola, J.A. and M.D. Cole. 1986. Constitutive c-myc oncogene expression blocks mouse erythroleukemia cell differentiation but not commitment. Nature 320: 760-763.

Constantinides, P.G., P.A. Jones, and W. Gevers. 1977. Functional striated muscle cells from nonmyoblast precursors following 5-azacytidine treatment. Nature 267: 364-366.

Constantinides, P.G., S.M. Taylor, and P.A. Jones. 1978. Phenotypic conversion of cultured mouse embryo cells by azapyrimidine nucleosides. Dev. Biol. 66: 57-71.

Cronmiller, C., P. Schedl, and T.W. Cline. 1988. Molecular characterization of daughterless, a drosophila sex determination gene with multiple roles in development. Genes Dev. 2: $1666-1676$.

Davis, R.L., H. Weintraub, and A.B. Lassar. 1987. Expression of a single transfected cDNA converts fibroblasts to myoblasts. Cell 51: 987-1000.

Denis, N., S. Blanc, M.P. Leibovitch, N. Nicolaiew, F. Dautry, M. Raymondjean, J. Kruh, and A. Kitzis. 1987. c-myc oncogene expression inhibits the initiation of myogenic differentiation. Exp. Cell Res. 172: 212-217.

Dmitrovsky, E., W.M. Kuehl, G.F. Hollis, H.R. Kirsch, T.P. Bender, and S. Segal. 1986. Expression of a transfected human c-myc oncogene inhibits differentiation of a mouse erythroleukaemia cell line. Nature 322: 748-750.

Endo, T. and B. Nadal-Ginard. 1986. Transcriptional and posttranscriptional control of c-myc during myogenesis: Its mRNA remains inducible in differentiated cells and does not suppress the differentiated phenotype. Mol. Cell. Biol. 6: $1412-1421$.

Falcone, G., F. Tato, and S. Alema. 1985. Distinctive effects of the viral oncogenes $m y c$, erb, fps, and $s r c$ on the differentiation program of quail myogenic cells. Proc. Natl. Acad. Sci. 82: 426-430.

Feinberg, A.O. and B. Vogelstein. 1983. A technique for radiolabeling DNA endonuclease fragments to high specific activity. Anal. Biochem. 132: 6-13.

Florini, J.R., A.B. Roberts, D.Z. Ewton, S.L. Falen, K.D. Flanders, and M.B. Sporn. 1986. Transforming growth factor $-\beta$. A very potent inhibitor of myoblast differentiation, identical to the differentiation inhibitor secreted by Buffalo rat liver cells. J. Biol. Chem. 261: 16509-16513.

Garfinkel, L.I., M. Periasamy, and B. Nadal-Ginard. 1982. Cloning and characterization of cDNA sequences corresponding to myosin light chains 1,2 and 3 , troponin-C, troponin-T, $\alpha$-tropomyosin and $\alpha$-actin. J. Biol. Chem. 257: 11078-11086.

Gorman, C., G.T. Merlino, M.C. Willingham, I. Pastan, and B.H. Howard. 1982. The Rous sarcoma virus long terminal repeat is a strong promoter when introduced into a variety of eucaryotic cells by DNA-mediated transfection. Proc. Natl. Acad. Sci.79: 6777-6781.

Gossett, L.A., W. Zhuang, and E.N. Olson. 1988. Dexamethasone-dependent inhibition of differentiation of C2 myoblasts bearing steroid-inducible N-ras oncogenes. I. Cell Biol. 106: 2127-2138.

Graham, F.L. and A.J. van der Eb. 1973. A new technique for the assay of infectivity of human adenovirus DNA. Virology 52: 456-467.

$\mathrm{Hu}$, J.S. and E.N. Olson. 1988. Regulation of differentiation of the $\mathrm{BC}_{3} \mathrm{Hl}$ muscle cell line through cAMP-dependent and -independent pathways. J. Biol. Chem. 263: 19670-19677.

Jaynes, J.B., J.E. Johnson, J.N. Buskin, C.L. Gartside, and S.D. Hauschka. 1988. The muscle creatine kinase gene is regulated by multiple elements, including a muscle-specific enhancer. Mol. Cell. Biol. 8: 62-70.

Jones, P.A. and S.M. Taylor. 1980. Cellular differentiation, cytidine analogs and DNA methylation. Cell 20: 85-93.
Kelly, K., B.H. Cochran, C.D. Stiles, and P. Leder. 1983. Cellspecific regulation of the c-myc gene by lymphocyte mitogens and platelet-derived growth factor. Cell 35: 791-800.

Kelvin, D.J., G. Simard, A. Sue-A-Quan, and J.A. Connolly. 1989. Growth factors, signaling pathways, and the regulation of proliferation and differentiation in $\mathrm{BC}_{3} \mathrm{Hl}$ muscle cells. II. Two signaling pathways distinguished by pertussis toxin and a potential role for the ras oncogene. J. Cell. Biol. 108: $169-176$.

Kimes, B.W. and B.L. Brandt. 1976. Characterization of two putative smooth muscle cell lines from rat thoracic aorta. Exp. Cell. Res. 98: 349-366.

Konieczny, S.F. and C.P. Emerson, Jr. 1984. 5-Azacytidine induction of stable mesodermal stem cell lineages from 10T1/2 cells: Evidence for regulatory genes controlling determination. Cell 38: 791-800.

1985. Differentiation, not determination, regulates muscle gene activation: Transfection of troponin I genes into multipotential and muscle lineages of $10 \mathrm{~T}^{1 / 2}$ cells. Mol. Cell. Biol. 5: 2423-2432.

Konieczny, S.F., A.S. Baldwin, and C.P. Emerson, Jr. 1986. Myogenic determination and differentiation of $10 \mathrm{~T}^{1 / 2}$ lineages: Evidence for a single genetic regulatory system. In Molecular and cellular biology, New Series leds. C. Emerson, D.A. Fischman, B. Nadal-Ginard, and M.A.W. Siddiqui), vol. 29, pp. 21-34. Alan R. Liss, New York.

Konigsberg, I.R. 1971. Diffusion-mediated control of myoblast fusion. Dev. Biol. 26: 133-152.

Kozak, M. 1984. Point mutations close to the AUG initiator affect the efficiency of translation of rat preproinsulin in vivo. Nature 308: 241-246.

Lassar, A.B., B.M. Paterson, and H. Weintraub. 1986. Transfection of a DNA locus that mediates the conversion of $10 \mathrm{~T}^{1} 1 / 2$ fibroblasts to myoblasts. Cell 47: 649-656.

Lathrop, B.K., E.N. Olson, and L. Glaser. 1985. Control by fibroblast growth factor of differentaition in the $\mathrm{BC}_{3} \mathrm{Hl}$ cell line. J. Cell Biol. 100: 1540-1547.

Linkhart, T.A., C.H. Clegg, and S.D. Hauschka. 1981. Myogenic differentiation in permanent clonal myoblast cell lines: Regulation by macromolecular growth factors in the culture medium. Dev. Biol. 86: 19-30.

Maniatis, T., E.F. Fritsch, and J. Sambrook. 1982. Molecular cloning: A laboratory manual. Cold Spring Harbor Laboratory, Cold Spring Harbor, New York.

Munson, R., K.L. Caldwell, and L. Glaser. 1982. Multiple controls for the synthesis of muscle-specific proteins in $\mathrm{BC}_{3} \mathrm{Hl}$ cells. J. Cell Biol. 92: 350-356.

Murre, C., P.S. McCaw, and D. Baltimore. 1989. A new DNA binding and dimerization motif in immunoglobuln enhancer binding, daughterless, $M y o D$, and myc proteins. Cell 56: $777-783$.

Olson, E.N., K.C. Caldwell, J.I. Gordon, and L. Glaser. 1983. Regulation of creatine phosphokinase expression during differentiation of the $\mathrm{BC}_{3} \mathrm{Hl}$ muscle cell line. J. Biol. Chem. 258: 2644-2652.

Olson, E.N., L. Glaser, J.P. Merlie, R. Sebbane, and J. Lindstrom. 1984. Regulation of the surface expression of acetylcholine receptors in response to serum and cell growth in the $\mathrm{BC}_{3} \mathrm{Hl}$ muscle cell line. J. Biol. Chem. 258: 13946-13952.

Olson, E.N., E. Sternberg, J.S. Hu, G. Spizz, and C. Wilcox. 1986. Regulation of myogenic differentiation by type beta transforming growth factor. J. Cell Biol. 103: 1799-1805.

Olson, E.N., G. Spizz, and M.A. Tainsky. 1987. The oncogenic form of $\mathrm{N}$-ras or $\mathrm{H}$-ras prevents skeletal myoblast differentiation. Mol. Cell. Biol. 7: 2104-2111.

Payne, P.A., E.N. Olson, P. Hsiau, R. Roberts, M.B. Perryman, and M.D. Schneider. 1987. An activated c-Ha-ras allele 
blocks the induction of muscle-specific genes whose expression is contingent on mitogen withdrawal. Proc. Natl. Acad. Sci. 84: 8956-8960.

Pinney, D.F., D.F. Pearson-White, S.F. Konieczny, K.E. Latham, and C.P. Emerson, Jr. 1988. Myogenic lineage determination and differentiation: Evidence for a regulatory gene pathway. Cell 53: 781-793.

Pinset, C. and R.G. Whalen. 1984. Manipulation of medium conditions and differentiation in the rat myogenic cell line L6. Dev. Biol. 102: 269-277.

Prochownik, E.V. and J. Kukowska. 1986. Deregulated expression of c-myc by murine erythroleukaemia cells prevents differentiation. Nature 322: 848-850.

Roman, D., J. Billadello, J. Gordon, A. Grace, B. Sobel, and A. Strauss. 1985. Complete nucleotide sequence of dog heart creatine kinase mRNA: Conservations of amino acid sequence within and among species. Proc. Natl. Acad. Sci. 82: 8394-8396.

Schneider, M.D., M.B. Perryman, P.A. Payne, G. Spizz, R. Roberts, and E.N. Olson. 1987. Autonomous expression of c-myc in $\mathrm{BC}_{3} \mathrm{Hl}$ cells partially inhibits but does not prevent myogenic differentiation. Mol. Cell. Biol. 7: 1973-1977.

Schubert, D., A.J. Harris, C.E. Devine, and S. Heinemann. 1974. Characterization of a unique muscle cell line. J. Cell Biol. 61: 398-413.

Sejersen, T., J. Suemegi, and N.R. Ringertz. 1985. Density-dependent arrest of DNA replication is accompanied by decreased levels of c-myc mRNA in myogenic but not differentiation-defective myoblasts. I. Cell. Physiol. 125: 465470.

Spizz, G., D. Roman, A. Strauss, and E.N. Olson. 1986. Serum and fibroblast growth factor inhibit myogenic differentiation through a mechanism dependent on protein synthesis and independent of cell proliferation. I. Biol. Chem. 261: 9483-9488.

Spizz, G., J.S. Hu, and E.N. Olson. 1987. Inhibition of myogenic differentiation by fibroblast growth factor or type betatransforming growth factor does not require persistent c-myc expression. Dev. Biol. 123: 500-507.

Sternberg, E.A., G. Spizz, W.M. Perry, D. Vizard, T. Weil, and E.N. Olson. 1988. Identification of upstream and intragenic regulatory elements that confer cell-type-restricted and differentiation-specific expression on the muscle creatine kinse gene. Mol. Cell. Biol. 8: 2896-2909.

Sternberg, E., G. Spizz, M.E. Perry, and E.N. Olson. 1989. A rasdependent pathway abolishes activity of a muscle-specific enhancer upstream from the muscle-creatine kinase gene. Mol. Cell. Biol. 9: 594-601.

Strauch, A.R. and P.A. Rubenstein. 1984. Induction of vascular smooth muscle $\alpha$-isoactin expression in $\mathrm{BC}_{3} \mathrm{Hl}$ cells. J. Biol. Chem. 259: 3152-3159.

Strauch, A.R., J.D. Offord, R. Chalkley, and P.A. Rubenstein. 1986. Characterization of actin mRNA levels during $\mathrm{BC}_{3} \mathrm{Hl}$ cell differentiation. J. Biol. Chem. 261: 849-855.

Tapscott, S.J., R.L. Davis, M.J. Thayer, P.-F. Cheng, H. Weintraub, and A.B. Lassar. 1988. MyoDl: A nuclear phosphoprotein requiring a myc homology region to convert fibroblasts to myoblasts. Science 242: 405-411.

Taylor, S.M. and P.A. Jones. 1979. Multiple new phenotypes induced in $10 \mathrm{~T}^{1 / 2}$ and $3 \mathrm{~T} 3$ cells treated with 5-azacytidine. Cell 17: 771-779.

1982. Changes in phenotypic expression in embryonic and adult cells treated with 5-azacytidine. J. Cell Physiol. 111: 187-194.

Thisse, B., C. Stoetzel, C. Gorostiza-Thisse, and F. PerrinSchmitt. 1988. Sequence of the twist gene and nuclear local- ization of its protein in endomesodermal cells of early Drosophila embryos. EMBO I. 7: 2175-2183.

Villares, R. and C.V. Cabrera. 1987. The acheate-scute gene complex of D. melanogaster: Conserved domains in a subset of genes required for neurogenesis and their homology to myc. Cell 50: 415-424.

Wright, W.E. 1984. Expression of differentiated functions in heterokaryons between skeletal myocytes, adrenal cells, fibroblasts and glial cells. Exp. Cell Res. 151: 55-69.

Wright, W.E. and J. Aronoff. 1983. The suppression of myogenic function in heterokaryons formed by fusing chick myocytes to diploid rat fibroblasts. Cell Diff. 12: 299-306.

Wright, W.E., D.A. Sassoon, and V.K. Lin. 1989. Myogenin, a factor regulating myogenesis, has a domain homologous to MyoD. Cell 56: 607-617.

Yaffe, D. and O. Saxel. 1977. Serial passaging and differentiation of myogenic cells isolated from dystrophic mouse muscle. Nature 270: $725-727$. 


\section{Corrigendum}

Genes \& Development 3: 628-640.

\section{A gene with homology to the myc similarity region of MyoD1 is expressed during myogenesis and is sufficient to activate the muscle differentiation program \\ Diane G. Edmondson and Eric N. Olson}

The sequence for the open reading frame of the mouse myogenin cDNA contains two errors, which were detected while sequencing the corresponding genomic clone. Codon 124 encodes Ser instead of His, and an additional dC is present at codon 155. This results in a frameshift in the carboxy-terminal portion of the protein. These errors have been confirmed by resequencing the cDNAs on both strands. The corrected sequence is shown below and has been submitted to GenBank.

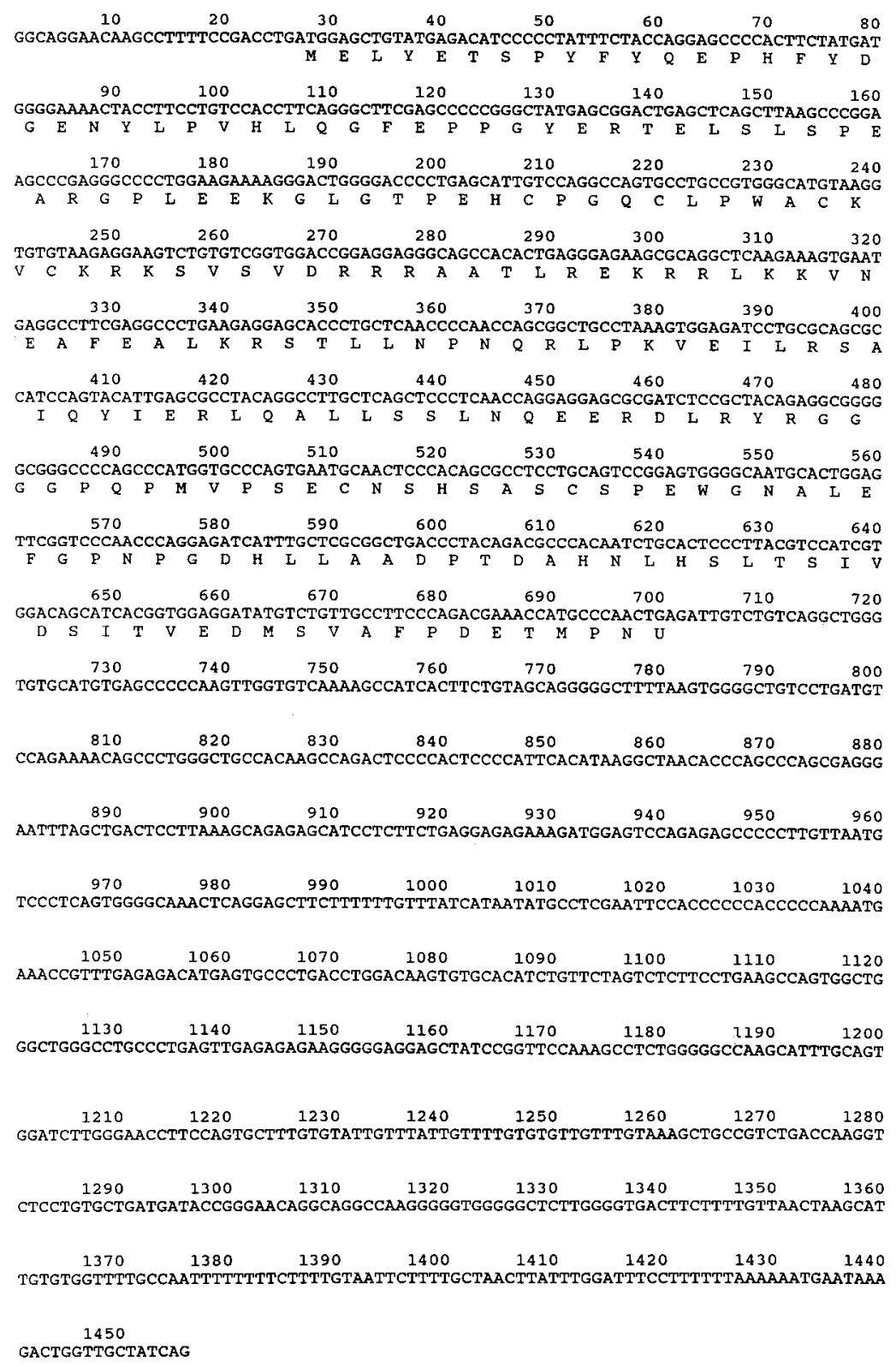




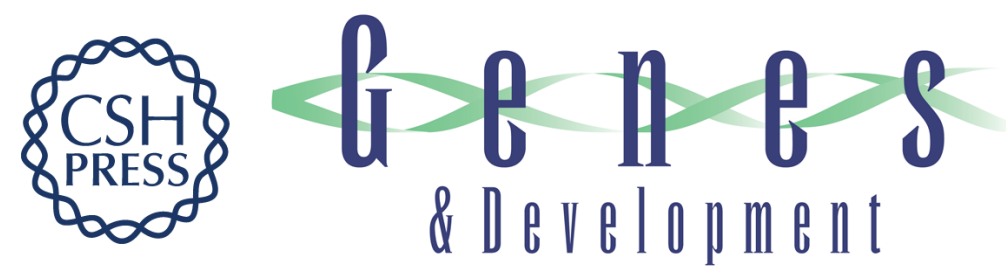

\title{
A gene with homology to the myc similarity region of MyoD1 is expressed during myogenesis and is sufficient to activate the muscle differentiation program.
}

D G Edmondson and E N Olson

Genes Dev. 1989, 3:

Access the most recent version at doi:10.1101/gad.3.5.628

\begin{abstract}
Related Content A gene with homology to the myc similarity region of MyoD1 is expressed during myogenesis and is sufficient to activate the muscle differentiation program Diane G. Edmondson and Eric N. Olson

Genes Dev. August , 1990 4: 1450

References This article cites 68 articles, 31 of which can be accessed free at: http://genesdev.cshlp.org/content/3/5/628.full.html\#ref-list-1

Articles cited in:

http://genesdev.cshlp.org/content/3/5/628\#related-urls

License Email Alerting
Service $\begin{aligned} & \text { Receive free email alerts when new articles cite this article - sign up in the box at the top } \\ & \text { right corner of the article or click here. }\end{aligned}$
\end{abstract}

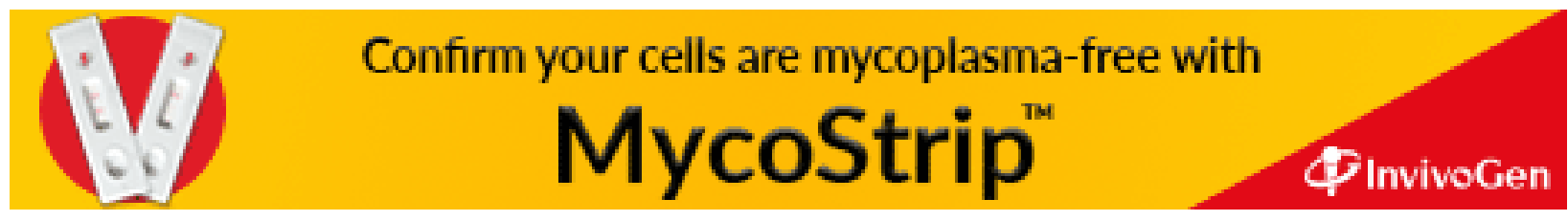

